\title{
PROFIL PERILAKU AGRESIF SISWA DAN IMPLIKASINYA BAGI BIMBINGAN KONSELING
}

\author{
${ }^{1}$ Dita Kurnia Sari \\ ${ }^{1}$ Prodi Bimbingan dan Konseling Islam, Fakultas Dakwah dan Komunikasi, Universitas Islam Negeri Sunan \\ Ampel Surabaya \\ ditakurniasari.uun@gmail.com
}

\begin{abstract}
Aggressive behavior is an act of violence that harm, hurt, injure because it will harm the victim that was done on purpose in the form of active or passive, physically or verbally either in person or not. The purpose of this study was to determine the profile of aggressive behavior class XI SMA Laboratorium UM Malang. The method used in this research is descriptive analysis. The results showed that (1) the level of aggressive behavior in class XI SMA Laboratorium UM Malang high, (2) the level of aggressive behavior of male students are higher than female students, (3) the form of aggressive behavior of male students more patterns of behavior physically aggressive, active and direct, (4) the form of aggressive behavior more female students in the form of verbal aggressive behavior, passive and indirect.
\end{abstract}

Keyword: aggressive behavior, sex differences, senior high school

Copyright (C) 2016 IICET (Padang - Indonesia) - All Rights Reserved

Indonesian Institute for Counseling, Education and Theraphy(IICET)

\section{PENDAHULUAN}

Fenomena meningkatnya kasus penganiayaan, pengeroyokan, pencabulan, pemerkosaan, pencurian, penganiayaan, dan pemukulan, yang dilakukan oleh remaja merupakan salah satu indikator bahwa perilaku agresif di kalangan remaja menjadi masalah serius yang harus dicari solusinya. perilaku agresif menurut Myers (2012) merupakan perilaku fisik atau verbal yang dimaksudkan untuk menyebabkan kerusakan.

Meningkatnya perilaku agresif yang dilakukan remaja usia sekolah ditunjukkan oleh data Komisi Perlindungan Anak Indonesia yang menyebutkan bahwa kekerasan yang dilakukan oleh remaja pada tahun 2012 sebanyak 3871 kasus. Data tersebut diperkuat oleh hasil survey terhadap 1026 siswa SD, SMP dan SMA di sembilan provinsi di Indonesia, ditemukan fakta bahwa jumlah anak usia sekolah yang menjadi pelaku kekerasan di lingkungan sekolah sebesar 87,6\% dan kenaikan angka kejadian kenakalan remaja pada tahun 2012 mencapai 13,34\% jika dibandingkan tahun sebelumnya (detik.com, 10 Oktober 2012). Perilaku agresif juga dapat dilihat di lingkungan sekolah. Berdasarkan hasil wawancara dengan konselor SMA Laboratorium UM Malang pada 22 Oktober 2013 diketahui bahwa perilaku agresif siswa masih sering terjadi di sekolah. Perilaku agresif yang ditunjukkan siswa antara lain mengejek temannya dengan kata-kata kotor dan merusak sarana belajar mengajar yang ada di sekolah, seperti mencoret meja dan dinding kelas. Bentuk agresivitas lain yang diamati oleh peneliti melalui observasi adalah siswa biasanya memaki, berkata kotor, menghina, membentak, bergosip, menceritakan kejelekan teman, menyebarkan berita yang tidak menyenangkan kepada siswa lain dan mengucilkan teman.

Remaja cenderung berperilaku agresif karena masa remaja merupakan masa transisi. Santrock (2007) mendefinisikan masa remaja sebagai masa peralihan dari masa anak-anak ke masa dewasa. Pada tahap ini remaja mengalami perubahan biologis, kognitif dan sosio-emosional yang berpengaruh terhadap kondisi emosinya.

Perilaku agresif pada remaja terjadi karena banyak faktor diantaranya adalah self esteem yang rendah, perceraian (Esfandy, et al., 2009), biologis dan penolakan lingkungan (Twenge, 2007). Perilaku agresif tidak hanya dipicu oleh kejadian-kejadian di luar individu, namun juga dari bagaimana suatu kejadian diterima dan diproses secara kognitif (Berkowitz, 2003; Knorth, et al., 2007). Remaja yang berperilaku agresif seringkali 
untuk berperilaku agresif ketika menghadapi konflik atau kondisi yang tidak menyenangkan (Whitfield, 1999; Berkowitz, 2003).

Perilaku agresif yang dibiarkan akan berdampak buruk pada perkembangan remaja. Remaja yang mempunyai kecenderungan berperilaku agresif akan mengalami hambatan belajar, masalah interpersonal (Wilson, 2003) dan cenderung memiliki keterampilan sosial yang rendah (Hann, 2002). Pendapat tersebut diperkuat oleh penelitian Gentile (2004) yang menjelaskan bahwa anak yang berperilaku agresif umumnya memiliki prestasi akademik yang rendah dan mengalami kesulitan belajar.

Jika dilihat dari jenjang pendidikannya, usia remaja adalah siswa yang duduk di bangku Sekolah Menengah. Dalam hal ini jelas peran sekolah dirasa sangat penting selain peran keluarga dan lingkungan sekitar. Menurut Ma'ruf (2007) sekolah merupakan tempat yang seharusnya menyenangkan, aman dan sehat. Tempat dimana siswa dapat mengembangkan berbagai potensi yang mereka miliki. Ketika sekolah sudah menjadi tempat munculnya berbagai perilaku agresif, maka perilaku agresif akan dianggan hal yang biasa bagi siswa. Perilaku agresif yang tidak segera ditangani maka dampak buruk yang menyertai perilaku tersebut akan muncul.

Beberapa fakta yang diperoleh dari hasil-hasil penelitian tentang perilaku agresif dan dampak yang ditimbulkannya, maka perlu dilakukan upaya untuk mengurangi tingginya perilaku agresif siswa SMA. Salah satu upaya yang dapat dilakukan untuk mengurangi perilaku agresif siswa melalui layanan konseling sekolah. Corey (2012) menyatakan bahwa konseling dapat membantu individu untuk menemukan sumber-sumber pribadi (potensi dalam diri) agar bisa hidup lebih efektif.

Paparan di atas mendorong peneliti untuk melakukan kajian empiris mengenai profil perilaku agresif siswa dan implikasinya bagi bimbingan konseling (Studi Deskriptif terhadap siswa kelas XI SMA Laboratorium UM pada tahun ajaran 2013/2014.

\section{METODELOGI PENELITIAN}

Tujuan dari penelitian ini adalah melihat profil perilaku agresif siswa SMA Laboratorium UM Malang. Populasi penelitian ini semua siswa kelas XI SMA Laboratorium UM Malang. Sampel sejumlah 250 siswa diambil dengan menggunakan random sampling.

Metode yang digunakan dalam penelitian ini adalah analisis deskriptif untuk mengetahui gambaran perilaku agresif siswa. Sedangkan pendekatan penelitiannya menggunakan pendekatan kuantitatif. Pendekatan kuantitatif memungkinkan dilakukan pencatatn dan penganalisisan data hasil penelitian menggunakan perhitungan-perhitungan statistik. Pendekatan secara kuantitatif ini pada prinsipnya adalah untuk menjawab masalah penelitian dan menganalisa data hasil penelitian yang diperoleh melalui penyebaran instrument pengumpulan data. Instrumen pengumpulan data yang digunakan dalam penelitian ini, yaitu skala perilaku agresif.

\section{HASIL DAN PEMBAHASAN PENELITIAN}

Hasil penelitian terhadap perilaku agresif siswa SMA Laboratorium UM Malang didapatkan beberapa temuan yaitu:

1. Tingkat perilaku agresis siswa tergolong tinggi

Dari 250 sampel penelitian, diketahui bahwa 87 siswa menunjukkan tingkat perilaku agresif tinggi, 93 siswa masuk kategori perilaku agresif sedang dan 70 siswa kategori rendah.

2. Tingkat perilaku agresif dipengaruhi oleh jenis kelamin

Hasil analisis skala perilaku agresif menunjukkan bahwa siswa yang memiliki tingkat perilaku agresif tinggi dan sedang didominasi oleh siswa laki-laki. Hasil ini sejalan dengan

3. Terdapat perbedaan bentuk perilaku agresif yang dilakukan siswa perempuan dan laki-laki

Siswa perempuan cenderung melakukan bentuk perilaku agresif verbal, pasif dan tidak langsung, sedangkan siswa laki-laki cenderung melakukan bentuk perilaku agresif fisik, aktif dan langsung. Hasil tersebut bukan berarti bahwa siswa laki-laki tidak ada yang melakukan bentuk perilaku agresif verbal, pasif maupun tidak langsung, namun angkanya kecil. Begitu juga dengan siswa perempuan yang melakukan bentuk perilaku agresif fisik, aktif, langsung, angkanya tidak signifikan .

Bentuk perilaku agresif yang ditunjukkan oleh siswa perempuan seperti menyindir, membentak, mengejek, menyebarkan berita bohong terkait korban, mengadu domba, menggosip, memberikan komentar kasar di jejaring sosial, menolak berbicara dengan korban, tidak merespon ketika diajak berbicara oleh 
korban, tidak membalas sapaan korban dan menghapus pertemanan dengan korban di jejaring sosial. Sedangkan bentuk perilaku agresif yang ditunjukkan oleh siswa laki-laki antara lain memukul, menendang, mendorong korban, menggebrak meja, dan membanting pintu.

\section{PEMBAHASAN}

Hasil temuan terhadap profil perilaku agresif siswa SMA Laboratorium UM Malang menunjukkan bahwa siswa laki-laki dan perempuan memiliki tingkat perilaku agresif yang berbeda. Siswa laki-laki menunjukkan tingkat perilaku agresif yang lebih tinggi dibanding siswa perempuan. Hasil tersebut menguatkan hasil penelitian sebelumnya yang mengemukakan bahwa laki-laki memiliki tingkat perilaku agresif yang tinggi dibanding perempuan (Bjorkqvist \& Niemela,2002; Galen \& Underwood, 2007; Lagerspetz, Bjorkqvist, \& Peltonen, 2008; Eagly \& Steffen, 1986; Anderson \& Huesmann, 2007). Data lain yang mendukung temuan penelitian ini yaitu data dari National Centre Educational Statistic yang mencatat, pada tahun 2011, 40\% remaja laki-laki dan 32\% remaja perempuan di Amerika telah melakukan tindak kekerasan seperti penyerangan, perampokan, perkelahian geng, atau pemerkosaan pada usia 17 tahun.

Beberapa penelitian telah mengungkapkan penyebab perbedaan tingkat perilaku agresif antara laki-laki dan perempuan. Eagly \& Steffen (1986) berusaha menjelaskan hal tersebut dari sudut pandang peran sosial. Perbedaan jenis kelamin akan membawa harapan normatif tertentu bagi masyarakat dan lingkungannya. Masyarakat masih memegang anggapan bahwa laki-laki harus lebih kuat dan berani daripada perempuan. Dengan demikian, akan terbentuk keyakinan bahwa laki-laki yang berperilaku agresif adalah wajar. Menurut Shaffer (2004), pengaruh sosial memegang peran penting dalam hal perbedaan tingkat perilaku agresif antara laki-laki dan perempuan, seperti pola asuh orang tua. Sebagai contoh, orang tua biasanya lebih banyak memberikan pekerjaan-pekerjaan yang mengandalkan kemampuan fisik pada anak laki-laki. Secara dini anak laki-laki telah dikenalkan pada upaya mempertahankan kelangsungan hidup dengan mencari nafkah sendiri. Sedangkan untuk anak perempuan lebih cenderung diberi pekerjaan-pekerjaan yang lebih ringan dan dapat diselesaikan di dalam rumah. Hal penting dari pengaruh sosial yang menjelaskan mengapa laki-laki memiliki perilaku agresif tinggi adalah (1) norma-norma dan nilai yang dipakai oleh masyarakat, (2) aturan yang diterapkan dalam keluarga. Artinya, kecenderungan seseorang melakukan perilaku agresi ditentukan oleh kebudayaan setempat.

Dalam kehidupan nyata, kemungkinan untuk menampilkan perilaku agresif lebih besar pada pria daripada wanita. Di dalam laboratorium, sebagian besar penelitian menemukan bahwa pria lebih agresif, meskipun sejumlah kecil penelitian penting sama sekali tidak menemukan perbedaan jenis kelamin. Penelitian-penelitian tadi hanya mencerminkan perbedaan pria-wanita dalam hal impuls agresif, perilaku hasil belajar yang diperoleh berdasarkan ganjaran yang dialami pria dan wanita untuk agresi, dalam tekanan situasional lebih memperkuat agresi pria, atau dalam kombinasi dari beberapa faktor.

Selain faktor sosial, dikatakan Eagly \& Steffen (1986) bahwa perbedaan tingkat perilaku agresif juga dipengaruhi oleh cara berpikir yang berbeda tentang perilaku agresif antara laki-laki dan perempuan. Perempuan cenderung lebih waspada dan memikirkan akibat yang akan timbul dari perilaku agresif yang dilakukannya. Dalam sebuah penelitian, tampak bahwa dalam situasi bebas memilih, dimana kelayakan agresi menjadi tidak jelas, perempuan lebih tidakmenunjukkan perilaku agresif daripada laki-laki. Tetapi bila perempuan memperoleh ganjaran (reward) bila berperilaku agresif, tampak bahwa laki-laki dan perempuan menjadi sama tingkat perilaku agresifnya (Bushman, 1988). Perbedaan tingkat perilaku agresif antara laki-laki dan perempuan akan terlihat jelas saat mereka menginjak usia 4 tahun. Hal itu disebabkan karena pada usia ini, individu sudah mulai belajar dan mengenal perbedaan jenis kelamin. Berikutnya perbedaan tersebut akan berkurang dengan sendirinya pada saat memasuki usia remaja akhir. Hal tersebut dikarenakan individu sudah mulai matang dalam mengenali identitas gendernya (Bettencourt, B \& Miller, 2006)

Begitu juga dengan bentuk perilaku agresif yang ditunjukkan. Siswa perempuan cenderung melakukan bentuk perilaku agresif verbal, pasif dan tidak langsung, sedangkan siswa laki-laki cenderung melakukan bentuk perilaku agresif fisik, aktif dan langsung. Beberapa penelitian mengemukakan bahwa perilaku agresif tidak langsung dan verbal lebih banyak dilakukan oleh perempuan. Sedangkan perilaku agresif fisik paling banyak dilakukan oleh lali-laki (Archer, 2004; Owens, Shute, \& Slee, 2000). Laki-laki cenderung lebih impulsif mengekspresikan dorongan agresivitasnya dibanding perempuan yang lebih banyak menggunakan tanda perilaku agresif non verbal seperti ekspresi wajah dan pengabaian (Bettencourt \& Miller 2006). Perbedaan ini terletak pada cara mengekspresikan perilau agresif yang berbeda antara laki-laki dan perempuan. Crick (dalam Wasdrop, 2009) telah meneliti bahwa anak perempuan cenderung kurang terbuka dalam menunjukkan perilaku agresifnya.

\section{KESIMPULAN DAN SARAN}


Perilaku agresif adalah perbuatan kekerasan yang membahayakan, menyakitkan, melukai dan menimbulkan kerugian terhadap korban yang dilakukan dengan sengaja dalam bentuk aktif maupun pasif, fisik maupun verbal baik secara langsung atau tidak. Profil perilaku agresif siswa kelas XI SMA Laboratorium UM adalah sebagai berikut: (1) tingkat perilaku agresif siswa tinggi, (2) tingkat perilaku agresif siswa laki-laki lebih tinggi dibanding siswa perempuan, (3) bentuk perilaku agresif siswa laki-laki lebih banyak pada bentuk perilaku agresif fisik, aktif dan langsung, (4) bentuk perilaku agresif siswa perempuan lebih banyak pada bentuk perilaku agresif verbal, pasif dan tidak langsung

Perilaku agresif siswa merupakan masalah mendasar dalam layanan Bimbingan Konseling karena perilaku agresif merupakan awal dari munculnya perilaku salah suai. Hasil penelitian ini, membuat rekomendasi selanjutnya untuk pihak sekolah agar dapat bekerjasama dengan konselor untuk menyusun sebuah program layanan yang bersifat preventif maupun kuratif. Oleh karena itu konselor diharapkan memiliki kemampuan untuk terampil, menguasai dan mengaplikasikan pendekatan konseling yang efektif dan efisien dalam rangka mewujudkan layanan konseling yang profesional di sekolah. Serdangkan bagi peneliti selanjutnya untuk lebih fokus meneliti aspek-aspek lain yang berkaitan dengan agresifitas sehingga dapat menciptakan model bimbingan yang tepat.

\section{DAFTAR PUSTAKA}

Anderson, C.A., \& Huesmann, L.R. 2007. Human aggressión: A social-cognitive view. Dalam Hogg, M.A., Cooper, J. The sage handbook of social psychology: Sage Publication

Archer, J. 2004. Sex Differences in Aggression in Real World Setting: A Meta Analytic Review. Journal of General Psychology, 8 (4), 291-322

Berkowitz, L. 2003. Affect, aggression, and antisocial Behavior. Dalam Davidson, R.J, Scherer, K.R., Goldsmith, H.H. Handbook of Affective Sciences. Oxford: University Press. Hlm. 804-823.

Bettencourt, B., \& Miller, N. 2006. Gender Differences in Aggression as a Function of Provocation: A MetaAnalysis. Journal Psychological Bulletin, 119 (3), 422-447

Bjorkqvist, K., \& Niemela, P. 2002. Of mice and women: Aspects of female aggression. San Diego: Academic Press, Inc.

Bushman, Brad. J. \& Anderson, Craig. A. 1998. “Human Aggression”. Academic Press. California. 1998

Corey, G. 2012. Theory and Practice of Counseling and Psychotherapy ( $8^{\text {th }}$ Ed.).Belmont, CA: Brook/Cole

Detik.com, 10 Oktober 2012. Tawuran: Pelajar Luka Terinjak-Injak. (Online), (http://detik.com), diakses 9 September 2013

Eagly, A. H., \& Steffen, V. J. 1986. Gender and Aggressive Behavior: A Meta- Analytic Review of the Social Psychological Literature. Journal Psychological Bulletin, 100 ( 3), 309-330

Esfandy, B., Bhardn, R., \& Nowsari, L. 2009. Background of inter parental conflicts and internalizing behaviour problems among adolescents. European Journal of Scientific Research, 37 (4), $599-607$.

Galen, B. R., \& Underwood, M. K. 2007. A developmental investigation of social aggression among children. Developmental Psychology, 33, 589-600.

Gentile, D.A., Lynch. P.L., Linder, J.R., \& Walsh, D.A. 2004. The effects of violent video game habits on adolescent hostility, aggressive behaviors, and school performance. Journal of Adolescence, 27, 5-24.

Hann, D.A. and Borek, N. 2002. Taking Stock of Risk Factors for Child/Youth Externalizing Behavior Problems. Bethesda, Maryland: National Institute of Mental Health, 3-4.

Knorth, E.J., Klomp, M., Van der Bergh, P. M., \& Noom, M. J. 2007. Aggresive adolescents in residential care: A selective review of treatment requirements and models. Adolescence, 42 (167), 461- 485.

Lagerspetz, K., Bjorkqvist, K., \& Peltonen, T. 2008. Is indirect aggression typical of females? Gender differences in aggressiveness in 11- to 12-year-old children. Aggressive Behavior, 14, 403-414.

Myers, D. G. 2012. Social Psychology (Psikologi Sosial). Alih Bahasa Aliya Tusani, dkk. Jakarta: Salemba Humanika

Owens, L., Shute, R., \& Slee, P. 2000. I'm in and you're out...Q: Explanations for teenage girls' indirect aggression. Psychology, Evolution, and Gender, 2, 19-46.

Santrock, J.W. 2007. Remaja. Jakarta: Penerbit Erlangga.

Shaffer, R. 2004. Social and Personality Development. Caalifornia: Brooks/Cole Publising Company 
Twenge, J. M., Ciarocco, N.J., Baumeister, R.F., DeWall, C.N., Bartels, J. M. 2007. Social exclusion decreases prosocial behavior. Journal of Personality and Social Psychology, 92 (1), 56-66.

Waasdrop, E.Tracy \& Bradshaw,P.C. 2009. Child and Parent Perceptions of Relational Aggression Within Urban Predominantly African American Children's Friendships: Examining Patterns of Concordance. Journal Child Fam Study, 18:731-745

Whitfield, G.W. 1999. Validating school social work: An evaluation of a cognitive-behavioral approach to reduce school violence. Research on Social Work Practice, 9 (4), 399-426.

Wilson, J.J. 2003. Preventing adolescent gang involvement. Juvenile Justice Buletin, 26 (2), 1-12. 